\title{
Histone H2B Type 3-B
}

National Cancer Institute

\section{Source}

National Cancer Institute. Histone H2B Type 3-B. NCI Thesaurus. Code C162987.

Histone H2B type 3-B (126 aa, $\sim 14 \mathrm{kDa}$ ) is encoded by the human H2BU1 gene. This protein plays a role in chromosome structure condensation. 